\title{
IMPLEMENTASI TPS UNTUK MENINGKATKAN KARAKTER GOTONG ROYONG, KETERAMPILAN BERKOMUNIKASI DAN HASIL BELAJAR IPS PESERTA DIDIK KELAS IXC DI SMPN 1 KANDEMAN
}

\section{Wulan Dwi Aryani}

SMP N 1 Kandeman-Batang, Indonesia

\begin{tabular}{l} 
Info Artikel \\
\hline Sejarah Artikel: \\
Disubmit Januari 2020 \\
Direvisi Maret 2020 \\
Diterima Mei 2020 \\
\hline Keywords: TPS, Gotong \\
royong, komunikasi dan \\
hasil belajar.
\end{tabular}

\begin{abstract}
Abstrak
Penelitian ini bertujuan untuk: (1) mengetahui implementasi TPS dalam pembelajaran, (2) meningkatkan karakter gotongroyong (3) meningkatkan keterampilan berkomunikasi, 4) meningkatkan hasil belajar IPS. Penelitian menggunakan desain spiral Kemmis \& Taggart. Subjek penelitian adalah 35 Peserta Didik kelas IXC. Hasil penelitian adalah sebagai berikut. (1) Pembelajaran dengan model TPS dapat diimplementasikan pada pembelajaran IPS kelas IXC di SMP N 1 Kandeman Batang, ada peningkatan rerata enam tahapan TPS, pada siklus I 64,58 (baik) dan siklus II 83,80 (sangat baik). (2) Ada peningkatan rerata indikator karakter gotongroyong pada siklus I 67,65 (baik) dan siklus II 83,10 (sangat baik). (3)Ada peningkatan rerata indikator keterampilan berkomunikasi, pada siklus I 56,10 (terampil), dan siklus II 83,80 (sangat terampil), 4) Ada peningkatan ketuntasan hasil belajar IPS peserta didik, pada siklus I ketuntasan belajar $50,00 \%$ rerata nilai 70,45 dan pada siklus II sebesar $88,24 \%$ rerata nilai 85,00
\end{abstract}

\begin{abstract}
This study aims to: (1) to know the TPS implementation learning, (2) increase to caracter gotongroyong; 3) increase comunication skills; (4) increase social studies outocomes. This research is a classroom action research, using a Kemmis \& taggart spiral design. The subjects of the research was 34 grade IXC students of SMPN1 Kandeman. The results of the study are as follows. (1) Learning with TPS can be implemented at Grade IXC of SMPN1 Kandeman, there is an average increase of six stages TPS, in the first cycle 64.58 (good) and in the second cycle, 83.30 (very good) (2) There is an increase average for indicators gotongroyong, in the first cycle 67.65 (good) and the second cycle 83.10 (very good). (3)There is an increase average for indicators comunication skill, in the first cycle 56.10 (skilled) and the second cycle 83.30 (very skilled) (4) There is an increasing mastery of students learning outcomes in social studies as shown in the first cycle $50 \%$ with had an average of 70.45 and in the second cycle it became $88.24 \%$ which had an average of 85.00 .
\end{abstract}

C 2020Universitas Negeri Semarang

$\begin{array}{lr}{ }^{凶} \text { Alamat korespondensi: } & \text { ISSN 2252-7133 } \\ \text { J1. Raya Kandeman Jl. Jendral Sudirman, Kunyaran, Kandeman, } & \text { E-ISSN 2548-4648 } \\ \text { Kec. Kandeman, Kabupaten Batang, Jawa Tengah 51261 }\end{array}$

E-mail: aryaniwulan@yahoo.co.id 


\section{PENDAHULUAN}

Tantangan guru dalam pelaksanaan pembelajaran dewasa ini semakin kompleks. Guru dihadapkan pada tuntutan masyarakat untuk menghadirkan pembelajaran yang lebih bermakna, penggunaan berbagai model pembelajaran, menciptakan pembelajaran yang lebih aktif, serta mengintegrasikan teknologi. Hal ini menuntut guru secara terus menerus berinovasi dan meningkatkan kemampuan, serta mengubah pola pembelajaran teacher centered menjadi student centered. Guru bertanggung jawab membantu peserta didik untuk mengembangkan sikap kritis, inovatif, kreatif, dan berakhlak mulia untuk menjadi manusia Indonesia seutuhnya.

Pendidikan karakter lahir tidak lepas dari fenomena dekadensi moral yang terjadi dalam pendidikan nasional, serta pada kehidupan masyarakat pada umumnya. Pentingnya penanaman karakter bangsa sebagai sebuah gerakan nasional telah dimulai dengan lounching pendidikan karakter yang dilakukan sejak tahun 2010 oleh Kementerian Pendidikan Nasional. Tindak lanjut dari program tersebut, pemerintah menetapkan kurikulum baru yang sarat muatan karakter, yakni kurikulum 2013.

Pembentukan karakter seperti diungkapkan Mumpuniarti (2012:248257), mencirikan nilai keberagaman yang berimplikasi pada terbentuknya perilaku menghormati dan menghargai orang lain (respect); keterbukaan dan positif dan penguatan dalam bentuk lisan, tulisan, isyarat, maupun hadiah terhadap keberhasilan peserta didik; memfasilitasi peserta didik melakukan refleksi untuk memperoleh pengalaman belajar yang telah dilakukan.

Lickona, (1991: 51) menyebutkan ada sepuluh perilaku manusia yang menandai kehancuran suatu bangsa yaitu: 1)meningkatnya kekerasan di kalangan remaja, 2) ketidak jujuran yang membudaya, 3)semakin tingginya rasa tidak hormat kepada orangtua, guru dan figur pemimpin, 4) pengaruh peer group terhadap tindakan kekerasan, 5) peningkatnya kecurigaan dan kebencian, 6)penggunaan bahasa yang memburuk, 7) penurunan etos kerja, 8) menurunnya rasa tanggungjawab individu dan warga negara, 9) tingginya perilaku merusak diri dan 10)semakin kaburnya pedoman moral. Ciri-ciri tersebut sebagian besar telah tampak pada peserta didik pada berbagai jenjang sekolah. Untuk itu harus ada upaya serius dan terpadu untuk menanamkan karakter pada peserta didik.

Peran penting Ilmu Pengetahuan Sosial (IPS) sebagai kajian ilmu sosial adalah pendukung peningkatan mutu pendidikan. Perkembangan teknologi yang semakin maju pesat di era global, menjadikan pendidikan IPS secara khusus harus mampu berperan dalam menghasilkan peserta didik yang berkualitas, yaitu manusia yang mampu berpikir kritis, kreatif, logis dan berinisiatif dalam menanggapi gejala dan masalah sosial yang berkembang dalam masyarakat. IPS diharapkan mampu mempersiapkan, membina dan membentuk kemampuan peserta didik yang menguasai sikap nilai dan keterampilan berkomunikasi yang diperlukan bagi kehidupan di masyarakat, sehingga dengan mempelajari IPS peserta didik dapat berpartisipasi di lingkungannya untuk dapat memecahkan masalah-masalah pribadi maupun masalah-masalah sosial atau kemasyarakatan.

Keterampilan berkomunikasi pada dasarnya merupakan kemampuan dalam berinteraksi yang dimiliki oleh peserta didik dengan orang lain baik di lingkungan sekolah maupun lingkungan sosial lainnya.Widoyoko (2013:28) menyebut keterampilan atau kecakapan sosial, meliputi 1) kecakapan berkomunikasi dengan empati yang adil (fairness); serta kepedulian (caring). Dengan demikian, karakter yang dibangun di sekolah akan melahirkan peserta didik yang cerdas, baik dari sisi intelektual yang dibuktikan dengan hasil belajarnya, sikap keseharian maupun kemampuan skillnya. Arah dari pendidikan karakter adalah sekolah, yang tidak sekedar menghasilkan lulusan dari sisi nilai, akan tetapi juga mampu melahirkan generasi baru yang berkarakter yang bermanfaat bagi dirinya sendiri, keluarga, masyarakat, bangsa, dan negara.

Proses pembelajaran IPS di SMP Negeri 1 Kandeman selama ini, guru masih menggunakan teksbook oriented yang berkesan tekstual, pola pembelajaran teacher centered. Ketika pembelajaran 
berlangsung, peserta didik belum secara aktif dilibatkan dalam pembelajaran, peserta didik cenderung pasif dan kurang aktif dalam mengikuti kegiatan pembelajaran. Peserta didik hanya duduk diam mendengarkan guru menyajikan materi, hal yang demikian membuat peserta didik kurang antusias mengikuti pembelajaran IPS sehingga pembelajaran menjadi sangat membosankan. Demikian juga ketika diskusi kelas berlangsung sebagian kecil peserta didik saja yang menyelesaikan kerja kelompok dan biasanya peserta didik yang aktif, sedang sebagian besar yang lain hanya duduk diam menunggu. Di sini terlihat tidak adanya keinginan bekerja sama/gotong royong utuk menyelesaikan tugas serta tidak adanya keinginan untuk berkompetisi secara positif dalam menyelesaikan tugas di antara peserta didik. Demikian juga ketika presentasi berlangsung tidak ada peserta didik yang terampil dalam berkomunikasi, peserta didik saling dorong dan saling tunjuk antar peserta didik.

Pembelajaran dengan teksbook oriented yang berkesan tekstual, pola pembelajaran teacher centered dan penggunaan model pembelajaran kurang variatif, rendahnya karakter gotongroyong, rendahnya keterampilan berkomunikasi diduga dapat berpengaruh terhadap hasil belajar Ilmu Pengetahuan Sosial peserta didik yang rendah. Hasil belajar IPS yang masih rendah salah satunya ditunjukkan dari data nilai kelas IX C yang di peroleh dari hasil penilaian harian sebelumnya yaitu, dari 34 peserta didik hanya 14 atau $41,18 \%$ peserta didik yang sudah mencapai KKM, sedang 20 peserta didik atau $58,82 \%$ belum mencapai KKM. Berdasarkan nilai penilaian harian tersebut rata-rata yang diperoleh kelas IXC 67,21.

Think-Pair Share (TPS) merupakan salah satu tipe pembelajaran kooperatif yang menekankan pada struktur-struktur khusus yang dirancang untuk mempengaruhi pola interaksi peserta didik dan memiliki tujuan untuk meningkatkan penguasaan materi pelajaran (Ibrahim, 2000: 25). Pembelajaran kooperatif tipe TPS, memiliki prosedur yang memberi lebih banyak waktu kepada peserta didik untuk berpikir, menjawab, dan saling membantu satu sama lain (Nurhadi,
2003: 66). Alasan pemilihan pembelajaran ini adalah supaya peserta didik dilatih bagaimana berdiskusi dalam kelompok untuk memecahkan masalah-masalah dalam pelajar IPS, mengkontruksi sendiri konsep-konsep pelajaran IPS malalui bimbingan guru, dengancara seperti ini maka peserta didik akan lebih mudah mengetahui jalinan keterkaitan antara konsep yang satu dengan konsep yang lainnya. Dengan demikian, peserta didik akan lebih mudah memahami tentang apa yamg mereka pelajari dan tidak mudah untuk melupakannya.

Berdasarkan latar belakang maka rumusan masalah adalah sebagai berikut: 1) Bagaimana implementasi Model TPS dalam Proses pembelajaran?; 2) Bagaimana implementasi Model TPS dapat meningkatkan karakter gotong royong peserta didik; 3) Bagaimana implementasi Model TPS dapat meningkatkan keterampilan berkomunikasi peserta didik; 4) Bagaimana implementasi Model TPS dapat meningkatkan hasil belajar IPS peserta didik Kelas IXC di SMPN 1 Kandeman. Adapun tujuan penelitian adalah: 1) untuk mengetahui implementasi model TPS dalam proses pembelajaran?, 2) untuk meningkatkan karakter gotong royong peserta didik; 3) untuk meningkatkan keterampilan berkomunikasi peserta didik; 4) untuk meningkatkan Hasil Belajar IPS peserta didik kelas IXC SMPN 1 Kandeman.

\section{METODE}

Penelitian ini adalah penelitian tindakan kelas (Classroom Action Reseach). Penelitian menggunakan desain Kemmis \& Taggart, action research develops through the self-reflective spiral: a spiral of cycles of planning, acting, (implementing plans), observing (systematically), reflecting... and than re-planning, futher implementations, observing and refelecting. Kemmis \& Taggart $(1990,22)$. Penelitian tindakan dikembangkan melalui reflektif spiral: siklus spiral meliputi: perencanaan, tindakan (implementasi tindakan), observasi, dan refleksi. Apabila hasil yang dicapai belum sesuai kriteria yang diharapkan, maka dilanjutkan dengan siklus berikutnya. 
Subjek penelitian ini adalah 34 peserta didik kelas IX C SMP Negeri 1 Kandeman Kabupaten Batang, terdiri atas 13 laki-laki dan 21 perempuan Alasan dipilih kelas ini adalah didasarkan pada pengalaman mengajar, peserta didik kelas IX C hasil belajar rendah, nilai rata-rata penilaian harian mata pelajaran IPS 67,45. Peserta didik yang mencapai Kriteria Ketuntasan Minimal 75 hanya $42,82 \%$ artinya masih ada $57,12 \%$ peserta didik belum mencapai KKM. Peserta didik cenderung pasif selama proses pembelajaran berlangsung, Pembelajaran dengan teks book oriented membuat suasana pembelajaran tidak menarik perhatian peserta didik terhadap materi, diskusi kelompok yang dibagi guru belum mampu memunculkan tanggungjawab dalam mengerjakan lembar kerja sehingga karakter gotongroyong peserta didik rendah dan keterampilan berkomunikasi rendah.

Prosedur penelitian dalam penelitian adalah sebagai berikut: 1). Perencanaaan (planning), Pada tahap perencanaan, kegiatan yang dilakukan meliputi: (a) membuat perencanaan pembelajaran (b) menyiapkan lembar kerja peserta didik, kisi-kisi soal tes hasil belajar, kisi-kisi pedoman observasi peserta didik dan guru (c) soal tes hasil belajar. 2.Pelaksanaan (action), Adapun skenario pembelajaran TPS Fase (a) Menyampaikan Tujuan dan memotivasi siswa. Fase (b) Mengajukan permasalahan Thinking berpikir. fase (c) Mengorganisasikan siswa dalam tim belajar Pairing (Berpasangan). fase (d) Berbagi dengan seluruh siswa Sharing (Berbagi). Fase (e) Melakukan evaluasi. Fase (f) Memberi Penghargaan. 3) Observasi (observation), Observasi dilaksanakan selama proses pembelajaran di kelas dengan menggunakan lembar observasi yang telah dibuat. Observasi dilakukan untuk melihat secara langsung pelaksanaan enam amatan indikator karakter gotong royong, enam amatan keterampilan berkomunikasi peserta didik. 4) Refleksi (reflection), Refleksi yang dilakukan berupa melakukan evaluasi terhadap apa yang telah dilakukan. Kekurangan yang ditemui pada siklus sebelumnya digunakan sebagai dasar penyusunan rencana tindakan pada siklus berikutnya dengan modifikasi atau perbaikan.

Teknik pengumpulan data dengan menggunakan observasi, tes hasil belajar, dokumentasi, sedangkan instrumen menggunakan pedoman observasi pengamatan peserta didik dan kinerja guru, soal penilaian harian, dan catatan lapangan di bantu camera smartphone

Teknik analisis data yang digunakan adalah analisis deskriptif komparatif yaitu membandingkan peningkatan hasil prasiklus dengan siklus I dan siklus II terhadap enam amatan indikator karakter gotongroyong peserta didik, enam amatan keterampilan berkomunikasi, lima amatan model TPS, dan Soal tes hasil belajar untuk mengukur hasil belajar kognitif, dengan cara; (a) memberikan skor yang sesuai untuk setiap butir pengamatan/soal. (b) menjumlahkan skor pada setiap aspek pengamatan/soal, (3) dicari besarnya nilai rata-rata masing-masing aspek amatan/soal.

\section{PEMBAHASAN}

\section{Hasil}

\section{a. Karakter gotong royong (Hasil Belajar Afektif)}

Data hasil belajar afektif berupa pengamatan terhadap enam indikator karakter gotong royong peserta didik kelas IX C SMP N 1 Kandeman selama pembelajaran. Hasil belajar afektif dapat dilihat pada tabel berikut:

Tabel 1. Nilai karakter gotong royong (Hasil Belajar afektif) Peserta didik pada Siklus I dan II

\begin{tabular}{|c|c|c|c|}
\hline \multirow{2}{*}{$\mathrm{No}$} & \multirow{2}{*}{ Aşek yang damati } & \multicolumn{2}{|c|}{ Niai pada tiap Sthus } \\
\hline & & I & II \\
\hline 1 & Berada dalam kelompok selama diskusi berlangsung & 69 & 79 \\
\hline 2 & $\begin{array}{l}\text { Keikutsertaan mencari informasi yang berkaitan } \\
\text { dengan tugas }\end{array}$ & 65 & 82 \\
\hline 3 & $\begin{array}{l}\text { Kelkutsertaan berkontribusi memberikan jawabn } \\
\text { tugas tim kelompok }\end{array}$ & 71 & 88 \\
\hline 4 & $\begin{array}{l}\text { Keikutsertaan menyelesaikan berbagai tugas dalam } \\
\text { kelompok }\end{array}$ & 72 & 84 \\
\hline 5 & Keikutsertaan mexiawab persoalan yang dibahas & 60 & 87 \\
\hline 6 & Keikutsertam dalam menyelesaikan tugas laporan & 69 & 82 \\
\hline & Ratarata & 57,65 & 83,10 \\
\hline & Kategui & Bẩ & Sangat Balle \\
\hline
\end{tabular}

Sumber: hasil penelitian 
Karakter gotong royong peserta didik siklus I rata-rata 67,65 kategori Terampil, dan siklus II 83,10 kategori sangat baik, hasil penelitian menunjukkan terjadi peningkatan dari siklus I ke siklus II sebesar 15,45. Rata-rata tiap indikator amatan keterampilan sosial mengalami peningkatan, adapun peningkatan setiap indikator amatan adalah sebagai berikut: 1) Berada dalam kelompok selama diskusi berlangsung terjadi peningkatan dari siklus I ke siklus II sebesar 10; 2) Keikutsertaan mencari informasi yang berkaitan dengan tugas terjadi peningkatan dari siklus I ke siklus II sebesar 17; 3) Keikutsertaan berkontribusi memberikan jawaban tugas tim/kelompok terjadi peningkatan dari siklus I ke siklus II sebesar 17; 4) Keikutsertaaan menyelesaikan berbagai tugas dalam kelompok terjadi peningkatan dari siklus I ke siklus II sebesar 12; 5) Keikutsertaan menjawab persoalan yang dibahas terjadi peningkatan dari siklus I ke siklus II sebesar 276 ) Keikutsertaan dalam menyelesaikan tugas/laporan terjadi peningkatan dari siklus I ke siklus II sebesar 13. Peningkatan setiap indikator amatan Karakter gotongroyong peserta didik dapat dilihat pada grafik berikut ini:

Gambar 1. Karakter Gotongroyong peserta didik Sumber: hasil penelitian

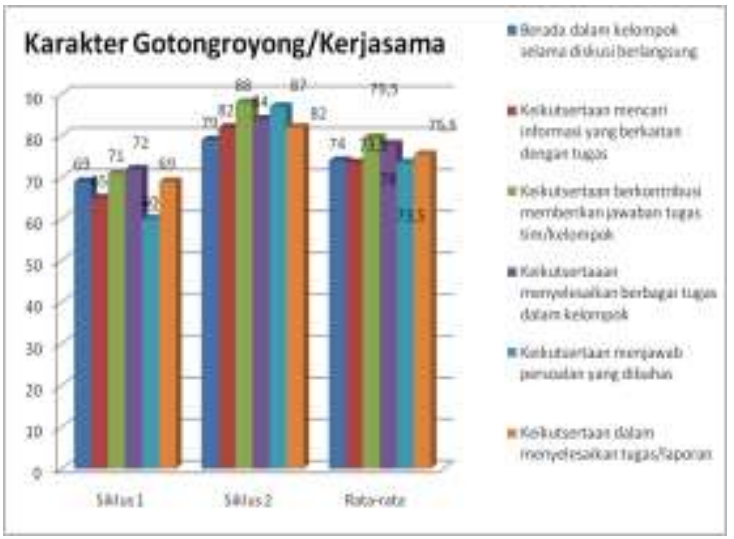

b. Keterampilan Berkomunikasi (Hasil Belajar

\section{Psikomotor)}

Data hasil belajar psikomotor berupa pengamatan terhadap enam indikator keterampilan berkomunikasi peserta didik kelas
IX C SMP N 1 Kandeman selama pembelajaran. Hasil belajar Psikomotor dapat dilihat pada tabel berikut:

Tabel 2. Nilai Keterampilan Berkomunikasi (Hasil Belajar Psikomotor) Peserta didik pada Siklus I dan II.

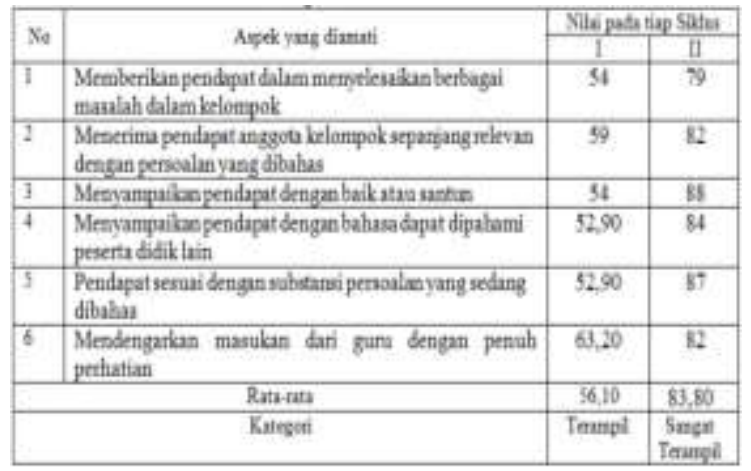

Sumber: hasil penelitian.

Keterampilan Berkomunikasi peserta didik siklus I rata-rata 56,10 kategori Terampil, dan siklus II 83,80 kategori Sangat Terampil, hasil penelitian menunjukkan terjadi peningkatan dari siklus I ke siklus II sebesar 27,70. Rata-rata tiap indikator amatan keterampilan sosial mengalami peningkatan, adapun peningkatan setiap indikator amatan adalah sebagai berikut: 1) Memberikan pendapat dalam menyelesaikan berbagai masalah dalam kelompok terjadi peningkatan dari siklus I ke siklus II sebesar 25; 2) Menerima pendapat anggota kelompok sepanjang relevan dengan persoalan yang dibahas terjadi peningkatan dari siklus I ke siklus II sebesar 23; 3) Menyampaikan pendapat dengan baik atau santun terjadi peningkatan dari siklus I ke siklus II sebesar 34; 4) Menyampaikan pendapat dengan bahasa dapat dipahami peserta didik lain terjadi peningkatan dari siklus I ke siklus II sebesar 31; 5) Pendapat sesuai dengan substansi persoalan yang sedang dibahas terjadi peningkatan dari siklus I ke siklus II sebesar 34; 6) Mendengarkan masukan dari guru dengan penuh perhatian terjadi peningkatan dari siklus I ke siklus II sebesar 18,80;

Peningkatan setiap indikator amatan Keterampilan Sosial peserta didik dapat dilihat pada grafik berikut ini: 


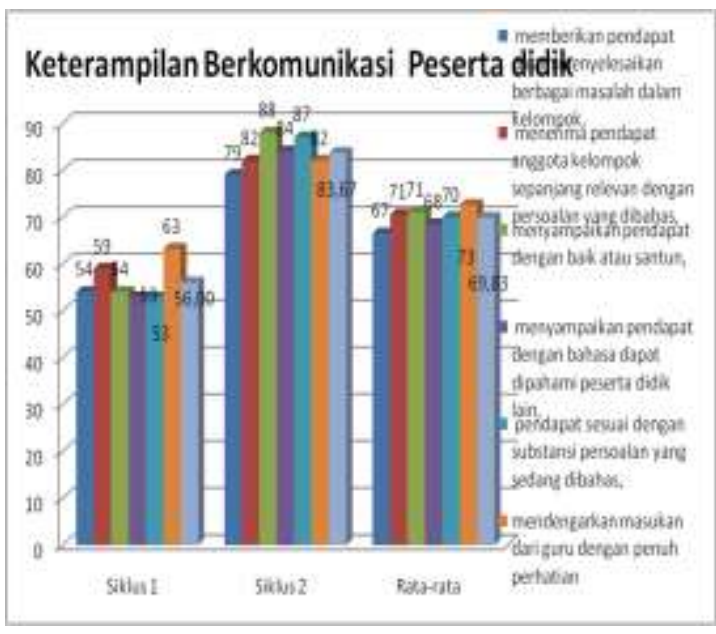

Gambar 2. Keterampilan Berkomunikasi Peserta didik

Sumber: hasil penelitian

\section{c. Hasil Belajar IPS Peserta Didik (Hasil Belajar Kognitif)}

Hasil belajar IPS berupa hasil belajar kognitif dapat dilihat pada tabel berikut:

Tabel 3. Nilai Hasil Belajar IPS Peserta Didik (Hasil Belajar Kognitif) Siklus I dan II

\begin{tabular}{|l|c|c|c|}
\hline \multirow{2}{*}{ No } & \multirow{2}{*}{ Uraian } & \multicolumn{2}{|c|}{ Hasil Belajar } \\
\cline { 3 - 4 } & & Siklus I & Siklus II \\
\hline 1. & Nilai terendah & 50,00 & 70,00 \\
2. & Nilai tertinggi & 80,00 & 95,00 \\
3. & Nilai Rata-rata & 70,45 & 85,00 \\
4. & Ketuntasan & $50,00 \%$ & $88,24 \%$ \\
& belajar (\%) & & \\
\hline
\end{tabular}

Sumber: hasil penelitian.

Hasil belajar kognitif peserta didik melalui implementasi TPS siklus I rata-rata 70,45 dan siklus II 85,00. Hasil penelitian menunjukkan terjadi peningkatan ketuntasan belajar peserta didik siklus I $50,00 \%$ dan siklus II $88,24 \%$. Nilai rata-rata peserta didik mengalami peningkatan dari siklus I ke siklus II yaitu meningkat sebesar 14,55. Peningkatan ketuntasan belajar peserta didik dari siklus I ke siklus II sebesar 38,24\%

Peningkatan hasil belajar kognitif peserta didik dapat dilihat pada grafik berikut ini:

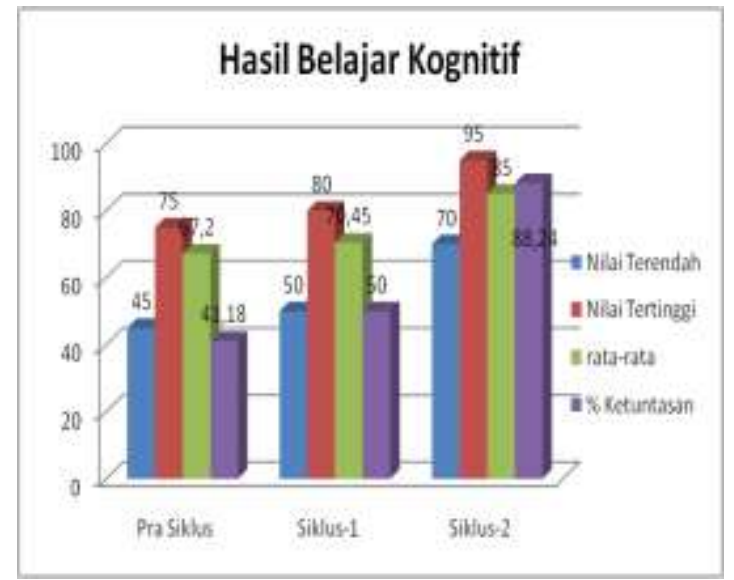

Gambar 3. Hasil Belajar IPS Peserta didik (Hasil Belajar Kognitif) Sumber: hasil penelitian

\section{d. Kinerja Guru melalui Implementasi TPS}

Kinerja guru dapat diketahui melalui kegiatan pembelajaran yang terjadi melalui enam tahapan TPS sebagai berikut:

Tabel 4. Nilai Kinerja Guru dengan Implementasi TPS Siklus I dan II.

\begin{tabular}{|c|c|c|c|}
\hline $\mathrm{No}$ & Tahap & SEble I & Stas II \\
\hline 1 & Menvancalkan tujuan dan menotivas sisma & 75 & 75 \\
\hline 2 & 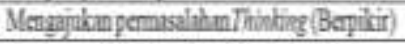 & 6250 & 8750 \\
\hline 3 & $\begin{array}{l}\text { Mengorgnisakan nisw dalim tim belaje } \\
\text { Pairing (Berpasangn). }\end{array}$ & 62,50 & 8750 \\
\hline 7 & $\begin{array}{l}\text { Babug dengne selunit siswa } \\
\text { Sharing (Bethag) }\end{array}$ & 62,50 & 8750 \\
\hline 5 & Melabukanevihas & 50,00 & 8750 \\
\hline \multirow[t]{2}{*}{6} & Mertken penflargan & 75 & 75 \\
\hline & Rathrata dan Kateanen & $6458(B)$ & $8330(58)$ \\
\hline
\end{tabular}

Sumber: hasil penelitian

Kinerja Guru melalui Implementasi TPS siklus I rata-rata 64,58 kategori Baik, dan siklus II 83,30 kategori Sangat Baik. Hasil penelitian menunjukkan terjadi peningkatan dari siklus I ke siklus II sebesar 18,72. Rata-rata tiap tahapan TPS mengalami peningkatan, adapun peningkatan setiap tahapan TPS adalah sebagai berikut: 1) Tahap penyampaian tujuan dan memotivasi peserta didik terjadi penimgkatan 0 ; 2) tahap mengajukan permasalahan "thinking"/berpikir terjadi peningkatan 25; 3)tahap mengorganisasi peserta didik ke dalam tim-tim belajar "pairing"/berpasangan terjadi 
peningkatan 25 ; 4) tahap berbagi dengan seluruh peserta didik "sharing"/berbagi terjadi peningkatan 25 ; 5) tahap evaluasi terjadi peningkatan 37,5 ; dan 6) tahap pemberian penghargaan terjadi peningkatan 0 .

Peningkatan nilai kinerja guru melalui Implementasi TPS dapat dilihat pada grafik berikut ini:

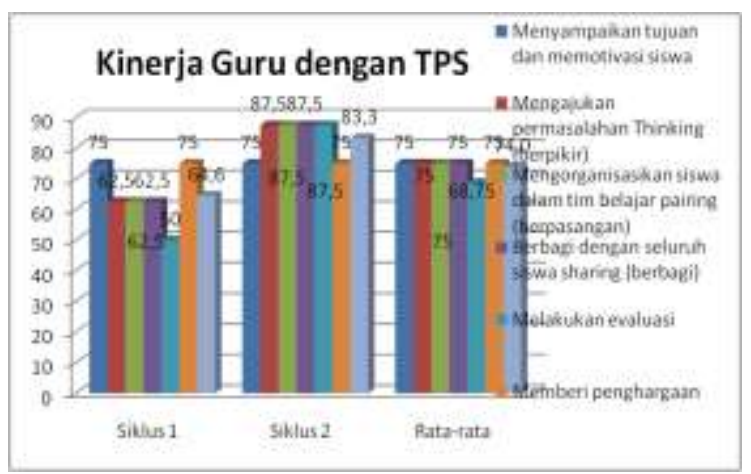

Gambar 4. Nilai Kinerja Guru melalui Implementasi TPS.

Sumber: hasil penelitian.

\section{Pembahasan}

Sebagian guru berpendapat bahwa mengajar dengan cara lama yang monoton dan terkesan teks books oriented tersebut dapat mengatasi adanya materi yang luas dengan alokasi waktu yang tersedia. Ternyata dari penelitian mengatakan bahwa hal tersebut tidak dapat menyelesaikan masalah yang ada. Sering kali tujuan yang hendak dicapai kurang berhasil optimal karena penggunaan model dan metode yang kurang variatif. Dalam pembelajaran memang tidak ada satupun model dan metode yang dapat menjamin keberhasilan tujuan yang dicapai. Penggunaan metode ceramah yang monoton akan membosankan dan akan menimbulkan kebosanan pada peserta didik, dan hanya menyentuh aspek kognitif saja sedangkan aspek afektif dan psikomotorik sering diabaikan.

Pembelajaran IPS melalui Implementasi TPS bisa menjadi solusi untuk memecahkan berbagai permasalahan peserta didik seperti kebosanan, masa bodoh, pasif dalam mengikuti pembelajaran. Pembelajaran dengan menggunakan model kooperatif berupa Implementasi TPS diharapkan ada perubahan suasana yang pada akhirnya peserta didik mampu meningkatkan karakter gotongroyong. Keterampilan berkomunikasi dan hasil belajar peserta didik secara komprehensif.

\section{a. Karakter Gotongroyong/kerjasama Peserta Didik (Hasil Belajar Afektif)}

Data hasil belajar afektif berupa pengamatan terhadap enam indikator amatan karakter gotongroyong peserta didik kelas IX C SMP N 1 Kandeman selama pembelajaran. Enam indikator amatan karakter gotongroyong selama proses pembelajaran mengalami peningkatan.

Peningkatan karakter gotongroyong peserta didik terjadi karena guru dalam pembelajaran menggunakan Implementasi TPS. Kemampuan yang dimiliki guru dalam pembelajaran mampu mendorong peserta didik dalam memunculkan karakter gotong royong terlihat ketika peserta didik berada dalam kelompok selama diskusi berlangsung dan keikutsertaan mencari informasi yang berkaitan dengan tugas kelompok, keikutsertaan berkontribusi memberikan jawaban tugas tim/kelompok, keikutsertaaan menyelesaikan berbagai tugas dalam kelompok berdampak pada suasana pembelajaran yang kondusif, peserta didik tidak gaduh dan ramai sehingga mampu menyelesaikan tugasnya dalam tim belajar, walaupun pada awalnya peserta didik cuek dan acuh terhadap kelompoknya karena anggota kelompok bukan berisi sahabat karib atau teman dekatnya, perlahan kondisi ini memudar peserta didik membaur dengan semangat dalam kerja tim belajar berusaha maksimal dalam menyelesaikan kartu soal yang diterimanya. keikutsertaan menjawab persoalan yang dibahas, keikutsertaan dalam menyelesaikan tugas/laporan berdampak konsentrasi peserta didik dalam menjawab kartu soal dalam diskusi berkolerasi terhadap ketenangan dan kecepatan tim dalam kelompok untuk menjawab persoalan yang ada dalam kelompok.

\section{b. Keterampilan Berkomunikasi Peserta Didik (Hasil Belajar Psikomotor)}


Keterampilan berkomunikasi peserta didik mengalami peningkatan karena dalam Implementasi TPS terdapat terdapat kegiatan think, phare dan share di awal kegiatan pembelajaran, dengan adanya think/berpikir berupa kartu soal membuat peserta didik tertantang untuk segera menyelesaikan kartu soal yang dimilikinya, karena skor dalam diskusi merupakan skor awal yang dicapai setiap kelompok dalam tim belajar, selain diskusi juga terdapat presentasi diakhir pertemuan pembelajaran. Pelaksanaan presentasi membuat masing-masing kelompok berusaha meningkatkan komunikasi dalam kelompoknya dengan harapan kelompok mereka mendapatkan skor tertinggi dalam kegiatan diskusidan presentasi tersebut, kelompok yang mendapat skor tertinggi akan menjadi tim yang terhebat/tim super.

Keterampilan berkomunikasi berupa kegiatan memberikan pendapat dalam menyelesaikan berbagai masalah dalam kelompok, menerima pendapat anggota kelompok sepanjang relevan dengan persoalan yang dibahas mampu melatih peserta didik untuk berkomunikasi dengan temannya dalam tim belajar, menyampaikan pendapat dengan baik atau santun, menyampaikan pendapat dengan bahasa dapat dipahami peserta didik lain perlu ditumbuhkembangkan karena peserta didik terbiasa menggunakan bahasa campuran antara bahasa Indonesia dan bahasa jawa, pendapat sesuai dengan substansi persoalan yang sedang dibahas, mendengarkan masukan dari guru dengan penuh perhatian.

Adanya think phare share yang dilaksanakan peserta didik mampu memunculkan kemampuan untuk mengeluarkan pendapat, yang sebelumnya sudah menjadi kebiasan bahwa untuk keterampilan dalam mengeluarkan pendapat sangat susah dilaksanakan peserta didik selama pembelajaran IPS berlangsung. Peserta didik juga memiliki kemampuan menerima masukan/pendapat dari anggota kelompok atau kelompok yang lain, bahasa yang digunakan dalam menyampaikan pendapat juga sudah runtut tidak bertele-tele, kemampuan dalam berbahasa yang baik dan santun serta mudah dipahami peserta didik yang lain memang keterampilan yang perlu dilatih sejak dini.

\section{c. Hasil Belajar IPS (Hasil Belajar Kognitif)}

Hasil belajar IPS berupa hasil belajar kognitif peserta didik, hasil belajar kognitif mengalami peningkatan setiap siklusnya, Peningkatan hasil belajar kognitif berkaitan dengan kinerja guru yang semakin baik selama pembelajaran berlangsung dan karakter gotongroyong, keterampilan berkomunikasi yang dimiliki peserta didik. Kemampuan guru dalam memfasilitasi peserta didik mencari informasi dan sumber belajar, mendorong keterlibatan aktif peserta didik serta memunculkan kreativitas dalam kelompok. Pembelajaran dengan implementasi TPS yang dipadukan dengan kartu soal dapat meningkatkan pemahaman peserta didik terhadap materi pembelajaran, peningkatan karakter gotongroyong, keterampilan berkomunikasi peserta didik berdampak pada peningkatan hasil belajar kognitif. Peningkatan hasil belajar kognitif juga terjadi karena guru tidak berhenti untuk selalu memotivasi peserta didik untuk giat belajar. peserta didik juga termotivasi dengan teman yang memiliki nilai tuntas KKM, peserta didik merasa malu jika nilai es hasil belajar tidak tuntas dan berusaha belajar supaya dapat tuntas KKM dengan lebih meningkatkan intensitas memperhatikan penyajian materi oleh guru dan ikut serta mencari informasi dalam menyelesaikan kerja tim belajar, kerja tim yang solid dalam diskusi dan presentasi yang dilakukan peserta didik meningkatkan hasil belajar kognitif peserta didik.

\section{d. Kinerja Guru dalam Pembelajaran IPS dengan Implementasi TPS}

Kinerja Guru dengan Implementasi TPS mengalami peningkatan, Peningkatan kinerja terjadi karena guru mampu menguasai enam Tahapan TPS selama pembelajaran berlangsung.

Tahap menyampaikan tujuan dan memotivasi siswa dapat dilaksanakan oleh guru 
dengan sangat baik, kegiatan diawali dengan berdoa dan presensi, guru mampu membuat suasana kelas hidup dan bersemangat karena pembelajaran diawali dengan menyanyikan lagu wajib nasional dengan berdiri dan serempak, motivasi dan semangat yang dimiliki setiap peserta didik dapat dijadikan modal awal dalam menyelesaikan kartu soal dalam diskusi, kegiatan penyampaian tujuan pembelajaran juga penting bagi keberhasilan proses pembelajaran dikelas.

Tahap mengajukan permasalahan Thinking (Berpikir) mampu dilaksanakan dengan sangat baik oleh guru, kegiatan diawali dengan guru menyajikan gambar untuk memunculkan imajinasi peserta didik, guru memandu peserta didik untuk melaksanakan kegiatan literasi untuk menumbuhkembangkan kemampuan menanya peserta didik, dan guru mengidentifikasi pertanyaan peserta didik, dengan bantuan gambar dan kegiatan literasi memudahkan peserta didik dalam memunculkan pertanyaan/kegiatan menanya.

Tahap mengorganisasi peserta didik dalam tim belajar Pairing (berpasangan) juga terlaksana dengan sangat baik, guru membagi kelompok dengan kategori tinggi, sedang dan rendah berdasarkan prestasi akademik kompetensi dasar sebelumnya. Hal ini bertujuan supaya setiap kelompok memiliki prestasi awal yang sama, tidak terjadi ketimpangan prestasi antar kelompok. Peserta didik yang awalnya enggan dan malas dengan anggota kelompoknya karena bukan sahabat karibnya perlahan mampu menerima anggota kelompoknya, guru mampu memberi pengertian bahwa semua teman adalah sama apakah itu sahabat atau bukan karena dalam diskusi dibutuhkan kerjasama dalam menyelesaikan persoalan dalam kelompok, dengan kemampuan yang dimiliki guru berdalam megorganisasi peserta didik berdampak pada kemampuan menyelesaikan kartu soal dalam kegiatan diskusi. Pembagian kelompok berdasarkan kategori $\mathrm{T}, \mathrm{S}$ dan $\mathrm{R}$ disetiap kelompoknya diharapkan terjadi kemampuan yang rata setiap kelompoknya dan kompetisi menjadi seimbang, tidak ada kelompok dengan kemampuan rata-rata tinggi semua kemampuan sama. Pembagian kelompok belajar juga memiliki pengaruh terhadap keberhasilan tim belajar dalm menyelesaikan tugas kelompoknya. Guru dalam menjelaskan model think phare share secara jelas dan rinci menjadikan kegiatan diskusi dan presentasi berjalan lancar,karena peserta didik langsung memahami apa yang menjadi tugas dan tanggungjawab peserta didik dalam tim belajar dalam menyelesaikan tugasnya.

Tahap berbagi dengan seluruh peserta didik sharing (berbagi) juga terlaksana dengan baik, pada tahap ini terlihat guru keliling kelas menuju meja-meja dalam tim belajar, guru memantau kerja setiap anggota dalam tim kelompok, Guru memberikan perhatian secara merata kepada semua anggota yang berada dalam tim belajar, peserta didik juga memanfaatkan kegiatan ini untuk bertanya terhadap materi atau hal-hal yang belum paham dan belum jelas supaya dapat menyelesaikan kartu soal diskusi, dalam tim belajar peserta didik ikut mencari informasi yang diperlukan dalam menjawab persoalan dalam kelompok tim belajar, Guru membimbing kegiatan presentasi tim belajar yang maju presentasi melakukan sharing dengan membacakan hasil diskusi kelompoknya, kemudian tim belajar yang lain menanggapi presentasi, bertanya dan memambahkan jawaban yang paling tepat dari materi presentasi kelaompok yang maju, kartu soal tipe A ditanggapi oleh tim lain yang memiliki kartu soal tipe A, demikian juga berlaku untuk kartu soal yang lain yaitu tipe $B, C$ dan $D$, terjadi interaksi yang komunikatif antara tim presentasi dan tim yang menanggapi, suasana pembelajaran menjadi hidup dan kondusif.

Tahap melakukan evaluasi dapat dilaksanakan dengan sangat baik oleh guru. Guru senantiasa memberi penguatan kepada peserta didik yang sudah melaksanakan tugas dengan baik, kemudian guru bersama peserta didik menyimpulkan materi hasil diskusi dan presentasi, dengan mengajukan pertanyaan-pertanyaan yang menjadikan peserta didik saling berebut untuk menjawab, hal ini 
berdampak pada terjaganya daya ingat peserta didik. Perhatian terhadap materi yang disajikan guru, kemampuan menyelesaikan kartu soal serta dalam diskusi dan materi presentasi tim bersama tim belajar memiliki kolerasi terhadap kemampuan peserta didik untuk menyelesaikan soal-soal penilaian harian/tes hasil belajar yang dilaksanakan di setiap akhir siklusnya. Guru melaksanakan tes hasil belajar, Guru selalu memotivasi bagi peserta didik untuk meningkatkan belajar peserta didik secara kognitif dengan menguasai kemampuan menyelesaikan soal kognitif 1 sampai kognitif 6 (mengingat, menjelaskan, menerapkan, memilah, menilai, mencipta). Kemampuan keterampilan sosial dan kemampuan kognitif yang dimiliki peserta didik diharapkan memiliki dampak bagi peserta didik dalam hidup di lingkungan bermasyarakat, peserta didik harus memiliki sikap kepedulian terhadap sesama dan lingkungan baik lingkungan sekolah, lingkungan masyarakat yang tujuan akhir adalah menjadi warga Negara yang baik, mampu hidup harmonis dengan alam dan masyarakat.

Tahap penberian penghargaan dilaksanakan dengan sangat baik. Guru senantiasa memberi upplause kepada setiap peserta didik yang mampu menjawab persoalan yang diberikan guru maupun pertanyaan dari peserta didik yang lain, penghargaan juga diberikan kepada tim-tim super yang memiliki nilai paling tinggi di setiap siklusnya, setiap kelompok yang tergabung dalam tim belajar akan memperoleh skor nilai dari menjawab kartu soal dalam diskusi dan kegiatan presentasi dari total skor yang diperoleh akan dijumlahkan untuk didapat tim yang terbaik/tim super, dengan adanya perghargaan mendorong semangat peserta didik dalam mengumpulkan point-point skor nilai yang tertinggi. Adanya reward dapat membuka kemungkinan terjadi kompetisi yang sehat antar kelompok demi mendapatkan skor yang tertinggi, sehingga dalam menyelesaikan tugas tim belajar diharapkan menghasilkan skor nilai yang maksimal sesuai yang diharapkan. Penghargaan yang diterima tim belajar yang terbaik menjadikan kebanggaan tersendiri bagi peserta didik dan anggota tim belajar lainnya, karena dengan kerja kerasnyalah tim belajarnya mampu menjadi yang terbaik/tim super. Tahap adanya pemberian pengakuan dan penghargaan mendorong semangat setiap kelompok dalam tim belajar berusaha maksimal melaksanakan kerja tim. Tak lupa guru selalu menyampaikan pesan moral kepada peserta didik bahwa para pahlawan membela tanah air dengan cara berkorban nyawa sedangkan peserta didik harus memiliki sikap nasionalisme dengan cara belajar yang rajin dan menjadi peserta didik yang berkarakter.

\section{SIMPULAN}

Berdasarkan hasil penelitian mengenai Implementasi TPS dapat disimpulkan sebagai berikut: 1) TPS dapat diimplementasikan pada pembelajaran IPS kelas IX C di SMP N 1 Kandeman Batang, ada peningkatan rata-rata dari enam tahapan TPS, pada siklus I rerata 64,58 (baik) dan siklus II rerata 83,80 (sangat baik); 2) Karakter gotongroyong peserta didik meningkat, siklus I dengan rerata nilai 67,65 (baik), dan pada siklus II dengan rerata nilai 83,10 (sangat baik); 3) Keterampilan berkomunikasi peserta didik meningkat, siklus I dengan rerata nilai 56,10 (terampil), dan pada siklus II dengan rerata nilai 83,80 (sangat terampil); 4) Ketuntasan hasil belajar peserta didik pada siklus I sebesar $50,00 \%$ rerata nilai 70,45 dan pada siklus II sebesar $88,24 \%$ rerata nilai 85,00 .

Adapun saran yang di rekomendasikan: 1) Guru dalam proses pembelajaran hendaknya dapat menggunakan model pembelajaran variatif sehingga mampu menumbuhkembangkan karakter, keterampilan berkomunikasi dan hasil belajar peserta didik; 2) Karakter gotongroyong dalam keikutsertaan menjawab persoalan yang dibahas perlu di budayakan; 3) Keterampilan berkomunikasi peserta didik dalam Memberikan pendapat dalam menyelesaikan berbagai masalah dalam kelompok perlu lebih di biasakan; 4) Hasil 
belajar perlu dikembangkan dengan pemberian soal yang HOTS

\section{DAFTAR PUSTAKA}

Ibrahim, Muhsin dkk. (2000). Pembelajaran Kooperatif. Surabaya; University Press

Lickona, T. (1991). Educating for Character: How Our Schools Can Teach Respect and Responsibility. New York: Bantam Books.
Mumpuniarti (2012). Jurnal Pendidikan Karakter. Tahun II, Nomor 3, Oktober 2012, halaman 248-257, Yogyakarta: UNY Press.

Nurhadi dkk. (2003). Pembelajaran Kontekstual dan penerapannya dalam KBK. Malang: Universitas Negeri Malang

Widoyoko, E. P. (2013). Evaluasi program pembelajaran, panduan praktis bagi pendidik dan calon pendidik. Yogyakarta: Pustaka Pelajar. 